\title{
Cine documental y genocidio. Algunos problemas éticos
}

\author{
Earth Made of Glass | Deborah Scranton | 2010 \\ Rwanda: The Untold Story | John Conroy | 2014 \\ Lior Zylberman*
}

CONICET | Centro de Estudios sobre Genocidio | UNTREF | FADU-UBA

Recibido: 20 de julio 2018; aceptado: 22 de octubre 2018

\begin{abstract}
Resumen
Este trabajo se desprende de una investigación en torno a las estrategias de representación de los genocidios en el cine documental. En esta ocasión, nos concentraremos en exponer algunos problemas éticos que puede suscitar la representación del genocidio en el cine documental. Teóricos del documental como Brian Winston, Carl Plantinga o Bill Nichols han planteado dos grandes ejes en torno a la ética y el documental: los deberes del realizador hacia el espectador -en términos de verdad-falsedad-y hacia los sujetos representados. El análisis de esta última dirección lleva a coincidir esas investigaciones con los análisis de los estudios sobre genocidio; es decir, el análisis del "elemento humano". Este escrito, entonces, propone un cruce entre el análisis de la tríada perpetrador-víctima-testigo (bystander) proveniente de los estudios sobre genocidio con aquellas perspectivas que han problematizado en términos éticos la representación de las personas en el cine documental. En el recorrido no sólo se buscará profundizar en ello sino también explorar qué otros roles puede el cine documental establecer en la representación de los diversos casos de genocidio.
\end{abstract}

Palabras clave: Cine Documental | Ética | Genocidio | Representación

Documentary film and genocide. Some ethical problems

\begin{abstract}
This article is part of an investigation about the representation of genocides in documentary film. On this occasion, we will concentrate on exposing some ethical problems that may arise in the representation of genocide in documentary films. Documentary theorists such as Brian Winston, Carl Plantinga, and Bill Nichols have set out two main axes around ethics and documentary: the duties of the filmmaker towards the spectator -in terms of truth-falsehood-and towards the subjects represented. The analysis of this last direction leads to coincide those investigations with the analysis of the genocide studies; that is, the analysis of the "human element". This article, then, proposes a cross between the analysis of the perpetrator-victimbystander theorized in the context of the genocide studies with those perspectives that have problematized in ethical terms the representation of people in Documentary film. Along the way, we will not only seek to deepen it but also explore what other roles documentary film can establish in the representation of various genocide cases.
\end{abstract}

Key Words: Documentary Film | Ethics | Genocide | Representation

\section{Introducción}

Se ha dicho y se sigue afirmando que el genocidio es el crimen de crímenes. Comprenderlo de este modo es una potente aseveración pero también puede ser riesgoso, conduciéndonos a transitar un camino ríspido y complejo al momento de pensar su representación. Desde esa perspectiva el genocidio queda cubierto en un halo de sacralidad y misterio distintivo; a su vez, al rotularlo de ese modo, su carácter moral y ético queda ya establecido -incluso podríamos decir determinado- de antemano. Sin poner en discusión esa rúbrica, la pregunta central de este trabajo, que se desprende de una investigación mayor en torno a la representación del genocidio en el cine documental,se concentra alrededor de algunos problemas éticos que puede suscitar la representación de este fenómeno en este estilo de cine.

Autores como Brian Winston, Bill Nichols o Carl Plantinga han meditado sobre la ética en el documental haciendo foco principalmente sobre dos ejes: los deberes

liorzylberman@gmail.com 
del realizador hacia el espectador -en términos de verdad-falsedad- y hacia los sujetos representados. Dichos ejes son los que de algún modo marcan la diferencia entre el documental y la ficción, y los ejemplos para fundamentar esta cuestión abundan. En la ficción, el director puede presentar una historia creando suspenso, ocultando información, puede hacer sufrir a sus personajes, incluso puede matarlos; y si los mata, los puede resucitar luego. Si maltrata a sus personajes, a lo sumo se llevará mal con los actores o con los espectadores. En el documental, en cambio, la relación entre sujeto y realizador es fundamental, éste no puede ser maltratado -ni mucho menos muerto- y la relación con la exhibición de la verdad resulta uno de los pilares fundamentales tanto para el documental como para la reputación del realizador.

En términos éticos, sugieren estos autores, al espectador se le debe garantizar que aquello que se representa realmente ocurrió, que los hechos coinciden con la realidad y que las evidencias que se presentan son prueba de ello; en otras palabras, no se debe engañar al espectador. Esta cuestión puede resultar un poco ríspida sobre todo si se piensa el documental en términos de tratamiento creativo; en esa dirección, Brian Winston sugiere que "las sensibilidades éticas del documentalista se han erosionado mucho debido a esta afirmación implícita constante sobre la licencia artística"(Winston, 2005, p. 181). Así, a pesar del anclaje en la realidad que requiere que se comporte éticamente, el documentalista busca en paralelo una creatividad que le permita ciertos grados de amoralidad justificada desde una mirada artística. La tensión entonces se produce en la presentación y manipulación de los hechos, de la evidencia y de la historia como también en los modos en que se llevan adelante las reconstrucciones: si la evidencia que se presenta debe tender hacia la verdad, lo mismo sucede con las reconstrucciones. A su vez, si el documental se diferencia no sólo de la ficción sino también del periodismo es porque, como señala Winston, el documentalista suele establecer un compromiso con los personajes de la película, mientras que el fin del periodista es exponer cierto saber a su público.

Para Bill Nichols, la pregunta en torno a una posible práctica ética no se trata de una interrogación más o de una mera pregunta retórica. A diferencia de organizaciones profesionales u otras instituciones o profesiones, los cineastas documentales no han adoptado un código ético que regule las normas de la profesión. De este modo, Nichols se pregunta qué obligación tiene el ci- neasta ya no para con los actores de los films de ficción, con quienes puede establecer una relación contractual bien definida, sino "para con personas reales cuyas vidas van más allá de los límites del encuadre y cuya conducta ante la cámara puede plantear graves problemas éticos, cuando no legales"(Nichols, 2007, p. 30). Si establecimos que el documental es, ante todo, una forma retórica audiovisual, el realizador, como al orador de la antigüedad, deberá ganarse la aprobación de los espectadores, a veces empleando fórmulas aceptadas y reconocidas, y no, como sugiere Nichols, suministrar una mera "transferencia de información".

Otro autor que ha estudiado los niveles éticos en el documental es Carl Plantinga. Sus reflexiones (Plantinga, 2007) se inician sugiriendo que un director de ficción no comete ninguna injusticia con los seres ficticios que aparecen en el film si se los presenta como cobardes, avaros o vulgares, como víctimas, culpables o estafadores ni tampoco le hieren sus sentimientos ya que, ante todo, no son seres humanos. ${ }^{1} \mathrm{Al}$ tratar con los personajes, un realizador o guionista de ficción debe hacer frente a los estereotipos, las ofensas al público o las palabras que utiliza en los diálogos, que no son otra cosa que obligaciones ante los espectadores ya que los personajes de ficción en sí, por más que estén basados en personas "reales", no poseen ningún derecho ni tampoco los directores contraen obligaciones para con ellos. En el documental, en cambio, las consideraciones éticas afectan tanto a las personas que aparecen en pantalla y que participan en el documental -y cuya forma de ser representadas es tarea del realizador- como también a aquellos a los que se refiere el documental en última instancia.

\section{Documental y Genocidio}

Para pensar la relación entre cine documental y genocidio resulta sugerente remarcar esta última línea. Siguiendo a Plantinga podemos preguntar cómo, al representar a un sobreviviente de un genocidio, no sólo se representa a la persona que, por ejemplo, brinda su testimonio, sino que también esa persona encarna a "la víctima" o a "los sobrevivientes": se representa a una persona pero también una idea de un grupo. En definitiva, "no puede dañarse a un personaje de ficción pero las posibilidades de herir a una persona real mediante su representación fílmica son enormes" (Plantinga, 2007, p. 48). 


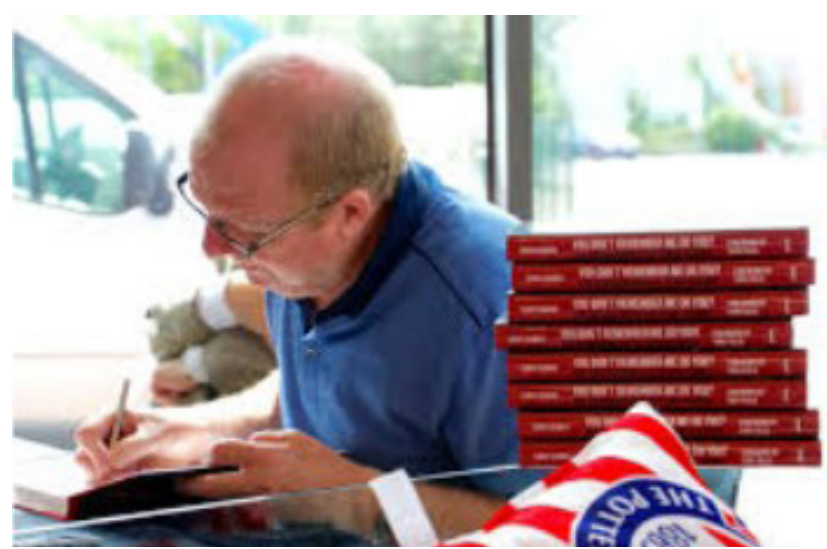

Ahora bien, aunque el cine documental se proponga ofrecer "lo real" no se debe pensar sus representaciones en términos de verdad transparente u objetiva. Incluso cuando brinda un retrato de una persona, el realizador las "caracteriza" ya que "les construye una imagen y les proporciona una identidad más que simplemente imitar $\mathrm{u}$ ofrecer un testimonio transparente de quiénes son dichos protagonistas" (Plantinga, 2007: 48). De este modo, al estudiar la ética en el documental, Plantinga sugiere reparar en los medios en que los documentalistas se basan para caracterizar a las personas y analizar cuáles son los principios éticos que rigen este proceso. El documentalista selecciona, resalta algún aspecto sobre otro, incluso toma una posición interpretativa histórica concreta: así, la caracterización que hace el realizador de las personas es de algún modo una construcción dramática. Ahí yace, afirma Plantinga, una paradoja inherente del documental: pese a que pretenda contar la verdad, revelarla no será sinónimo de ausencia de punto de vista o una perspectiva en concreto ya que "aunque intente ofrecer imágenes y sonidos que retraten con exactitud lo que sucedió delante de la cámara, estos no llegan a proyectar a la persona o al acontecimiento en su totalidad y tampoco pueden escapar al hecho de que la cinta no es más que un conjunto audiovisual que se grabó desde una de las múltiples perspectivas espaciales posibles" (Plantinga, 2007, p. 53). Resulta interesante reparar las cuestiones que señalo a partir de Plantinga en dos documentales sobre el genocidio ruandés. Earth Made of Glass (Deborah Scranton, 2010) presenta diversas historias sobre la reconstrucción de Ruanda luego del genocidio y cómo la comunidad internacional continúa imputando al Frente Patriótico Ruandés por crímenes cometidos durante la guerra civil. Uno de los protagonistas de este título es el mismo Paul Kagame, presidente de Ruanda desde el año 2000 y líder del FPR; en el documental, además de contarnos su historia, Kagame es caracterizado, ante todo, como un héroe, como un líder con una lucidez política y con una fuerte voluntad de transformar a Ruanda en un país venerado. En cambio, en Rwanda: The Untold Story(John Conroy, 2014), documental producido por la BBC al cumplirse los veinte años del genocidio, la misma persona es caracterizada como un líder despótico, autoritario e, incluso, responsable tanto del asesinato del presidente Juvénal Habyarimana -su avión cayó derribado en abril de 1994como del inicio del genocidio en 1994. Para todo documental, caracterizar a la persona en toda su complejidad es una tarea ardua y difícil de lograr, es por eso que antes de brindar una totalidad, los individuos son caracterizados desde una perspectiva determinada. Sin embargo, a pesar de que prime un punto de vista, a veces en forma más implícita otras en forma explícita -el documental de la BBC se propone contar la "verdad encubierta"-, sigue vigente el contrato tácito que se establece entre documentalista y espectador, es decir mostrar los hechos para que se sepa lo acontecido y, por otro lado, afirmar que en la película se presentan "verdades del mundo real": "el hecho de que la caracterización de las personas sea, hasta cierto punto, creativa y constructiva (y que no se limite meramente a copiar o reproducir) no elimina el requisito de veracidad" (Plantinga, 2007, p. 55).

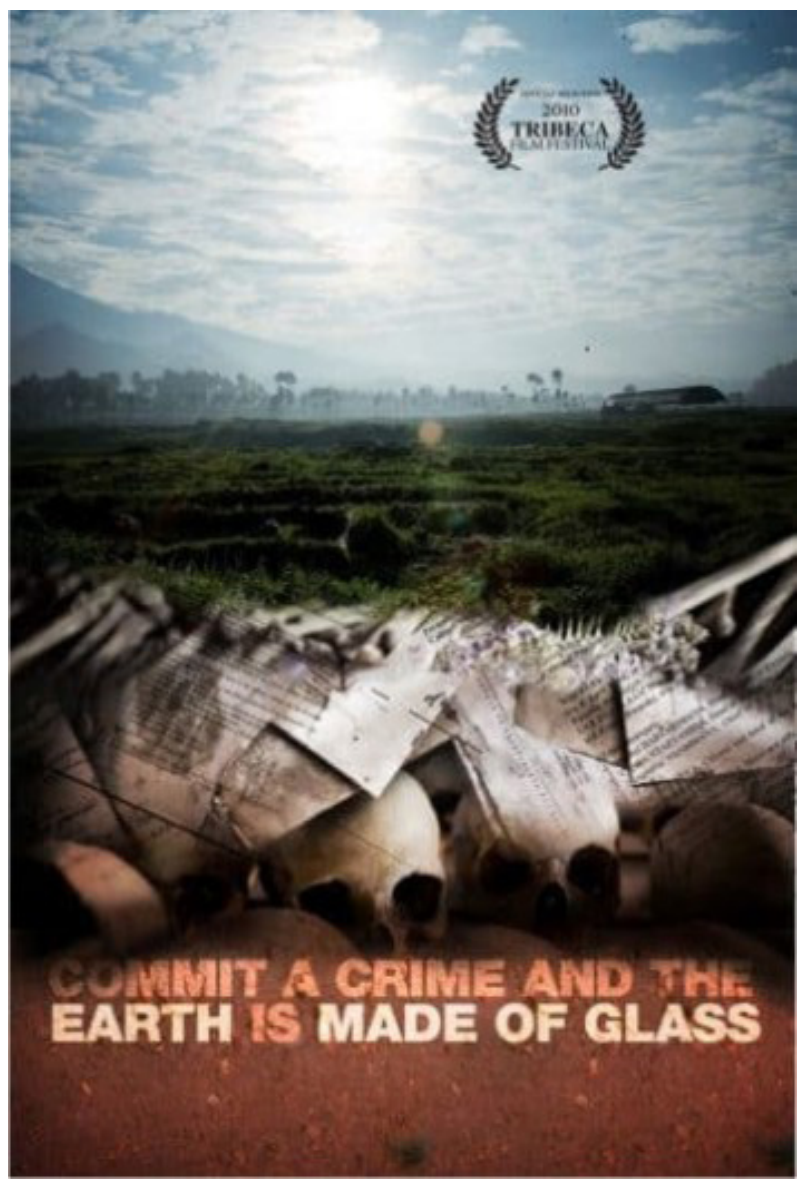


Los estudios sobre genocidio también han hecho hincapié en las personas, en "el elemento humano" (Alvarez, 2001, p. 18), haciendo referencia a la tríada propuesta por Raul Hilberg -víctimas, perpetradores, espectadores (bystanders)- y que de alguna manera u otra la mayoría de los investigadores sobre genocidio la han tomado ya sea para llevar adelantes sus estudios, focalizar en algunos de los actores o bien criticarlo. El propio Hilberg mencionó que estos actores no deben ser estudiados como estáticos o pasivos sino en su propia interacción. Por lo general se representa a la víctima en actitud pasiva, y es allí donde se fundamenta una de las críticas a este modelo: es verdad que las víctimas no tienen otra posibilidad que orientar sus acciones al poder abrumador del enemigo que las ataca; sin embargo, sus acciones también afectan a las de los perpetradores. Al pensar este paradigma y al efectuar diversos tipos de caracterización, el cine documental suele tipificar este modelo sin problematizarlo, reduciendo al genocidio a una tendencia moral de dos polos: el bien absoluto (la víctima o el sobreviviente) y el mal absoluto (el perpetrador). Esta tendencia se acentúa, justamente, a partir de la caracterización: el sobreviviente, en tanto víctima, sufre al dar su testimonio, como en The Last Days (James Moll, 1998) o Rwanda: Beyond the Deadly Pit(Gilbert Ndahayo, 2009); en cambio, el perpetrador, cuando testimonia, no se inmuta ante sus crímenes, se lo muestra frío y calculador, como en Escadrons de la mort: L'école française (Marie-Monique Robin, 2003), Duch, le maître des forges de l'enfer (Rithy Panh, 2011), o The Look of Silence (Joshua Oppenheimer, 2014). De este modo, el perpetrador queda representado como perteneciente a un grupo organizado y coherente motivado exclusivamente por el odio, que es la condición que habilita a presentarlos como pura maldad. Por otro lado, las víctimas no son representadas como actores activos sino fundamentalmente pasivos y, sobre todo, como meras víctimas. Desde ya que eso no implica afirmar que la víctima merecería la muerte sino pensar este esquema en forma activa, a los tres vértices como actores, influyendo sus acciones y reacciones en los otros.

\section{El elemento humano en el documental}

En continuidad con lo dicho, daré un paso más para pensar diversos tipos de caracterización. En el cine documental encuentro por lo menos seis actores que no son necesariamente presentados al mismo tiempo, a veces se focaliza en alguno en particular, otras se articula su participación a través del montaje, y en otras a través de un gran relato coral. ${ }^{2}$ Además de los tres actores ya mencionados, los documentales presentan y caracterizan como actores a las siguientes generaciones -hijos o nietos tanto de sobrevivientes como de perpetradores-, a los activistas y a los expertos - un actor que se posiciona en forma objetiva y desde una posición epistemológica de autoridad-.

Al pasar al estudio de la representación de la víctima se puede optar, al menos, por dos caminos. Por un lado, la víctima es representada por medio de su ausencia, sin voz ni cuerpo, a partir de las palabras de otros, como el caso de Namibia Genocide and the Second Reich (David Olusoga, 2005), un documental sobre el genocidio herero a principios del siglo XX, o incluso en el documental de denuncia Stop Genocide (Zahir Raihan, 1971) sobre Bangladesh. Así, es la voz de un otro y el material de archivo el que hace presente una ausencia, apelando como estrategia de representación a la mostración de los restos, ya sea a través de imágenes de archivo como en los registros en el presente.

El segundo camino, que puede estar interconectado con el anterior, es aquel que representa a la víctima-sobreviviente, posicionándose tanto como dicho actor y como testigo. Los primeros films documentales sobre los campos de concentración nazi no presentaban la voz de los sobrevivientes ya que en los registros realizados en los campos éstos actuaban como prueba corpórea de las atrocidades nazis antes que una voz precisa. Si bien desde la finalización de la guerra se publicaron testimonios escritos $^{3}$ y algunos documentales recurrieron a la voz de los sobrevivientes, ${ }^{4}$ esto fue más una excepción que una regla. Será recién con el juicio a Adolf Eichmann en 1961, como señala Annette Wieviorka, donde se produzca el advenimiento del testigo y, ya en las décadas de 1980 y 1990, el inicio de la era del testigo, ${ }^{5}$ Esta era colocará sobre el testigo un lugar particular en tanto sujeto ético y moral, siendo su palabra sagrada e indiscutible (Wieviorka, 2006).

En tanto víctima, el sobreviviente es caracterizado con un halo de integridad moral y de bondad, soportando sobre sus espaldas una pesada carga. Incluso si cometió faltas en su lucha por sobrevivir, la caracterización llevada adelante no juzga esas acciones, manteniendo así dicha posición ante el sobreviviente. En Gardiens de la mémoire (Eric Kabera, 2004), por ejemplo, no sólo nos muestran las actividades que llevan adelante diversos sobrevivientes para mantener viva la memoria del genocidio sino, que al presentarlos, el realizador los caracteriza 
también como guardianes morales de la Ruanda actual. En consonancia, la fórmula de representación que suele primar al momento de caracterizar al sobreviviente es la del martirio (Burucúa \& Kwiatkowski, 2014, p. 95), una persona que atestigua sobre un hecho conocido a partir de su propia experiencia pero no en términos judiciales sino porque al hacerlo se enfrentan a la posibilidad de un dolor: el mártir es una persona que padece sufrimientos o injusticias pero los sobrelleva y aguanta con sufrimiento y entereza. Así, en tanto mártir el sobreviviente, al dar su testimonio tiende a ser caracterizado como el que debe sufrir, debiendo la cámara registrar sus lágrimas -incluso siendo las lágrimas el vehículo de emoción y lazo afectivo con el espectador-. Cuando ello sucede, la pregunta que surge es ¿hasta dónde mostrar el sufrimiento del testigo? ¿Cuál es el límite de ese llanto? En The Last Days, el sobreviviente Bill Basch rompe en llantos al volver junto a su hijo al campo de Buchenwald, ${ }^{6}$ Ana, en Montoneros, una historia (Andrés Di Tella, 1994), también es retratada de ese modo, lo mismo que los diversos sobrevivientes -entre ellos el director cuando relata cómo fueron asesinados sus padres- en The Rwandan Night (Gilbert Ndahayo, 2013) o en The Conscience of Nhem En(Steven Okazaki, 2008).

El otro actor de importancia en el elemento humano es también el perpetrador. Si a la figura de la víctima-sobreviviente se la caracteriza en términos de bondad absoluta, al perpetrador se lo hará en términos de maldad radical, quitándole todo elemento humano para describirlo como sobrehumano. De este modo, si la víctima queda simplificada al lugar del sufriente, el perpetrador queda reducido a hacer el mal por el mal mismo; en consonancia, gran parte de los documentales que tratan sobre genocidio suelen caracterizar a los perpetradores de modo unidimensional, perdiendo de vista los matices que existen en este grupo. Sin embargo, al ahondar en aquellos que han estudiado a los perpetradores tratando de responder por qué la "gente normal" puede llegar a tramar un genocidio, comprenderemos que este actor resulta mucho más complejo; en su interior encontramos a los ideólogos, los funcionarios, el establishment-empresarios e incluso profesionales de diversas disciplinas-, y, por supuesto, la mano de obra: como señala Yves Ternon, entre los perpetradores de un genocidio existen los que se "ensucian las manos" y los que no (Ternon, 1995, pp. 121-123). A su vez, existe un elemento más a tener en consideración: como crimen, el genocidio posee lo que cualquier crimen inviste, esto es, un móvil. Para decirlo de otro modo, ante un genocidio alguien también busca beneficios, y esos beneficiarios también forman parte de los perpetradores.

Dar la voz al perpetrador plantea otros tipos de problemas éticos, distintos a los que se despliegan al presentar a la víctima. Dar la voz a los perpetradores abre una nueva serie de paradojas éticas, la primera, se concentra en lo recién expuesto: ¿por qué no deberíamos escuchar la voz del perpetrador? Escuchar su punto de vista nos ayuda a por lo menos tres cuestiones: efectivamente a confirmar el exterminio -si es que lo confirma, en entrevistas los líderes Khmer Rouge han negado los crímenes-, a saber, qué idea e imaginario construyó el perpetrador sobre la víctima y, finalmente, a vislumbrar qué imagen tienen de sí mismos.

Hay así, por lo menos, dos cuestiones éticas más para plantear en torno a la aparición del perpetrador en el cine documental. La primera incumbe al pago de la entrevista. En términos éticos, toda persona se supone que está dando su imagen a la cámara, al realizador, por lo tanto no resulta inmoral el pago por el tiempo dado a la cámara. Surge aquí un posible límite: ¿se le debe pagar al perpetrador para ser entrevistado? ¿Está el realizador dispuesto a pagar? ¿Qué pacto se crea entre el entrevistado y entrevistador por medio del dinero? ¿El perpetrador será honesto o dirá lo que sea para cobrar por su participación? Errol Morris le pagó por su intervención a Fred Leuchter, también lo hizo Claude Lanzmann con Franz Suchomel. El francés justificó su decisión en que otros nazis, al no mediar dinero, le habían negado entrevista, en cambio Suchomel "apreciaba el dinero por encima de cualquier otra cosa" y la cantidad que le había hablado le "apuñalaba el corazón" a Lanzmann (Lanzmann, 2011, p. 444). Sin embargo, a pesar de aceptar ser entrevistado y contarle detalles sobre Treblinka, el nazi no accedió a ser filmado y solicitó que su nombre no figurara en el film. Lanzmann, en cambio, nunca estuvo dispuesto ni a perder la posibilidad de filmar a Suchomel -recurrió a una cámara oculta- ni a no mencionar su nombre: no estaba decidido a respetar su palabra por mucho que prometiera que no lo haría.' De este modo, ¿qué acuerdo ético debe llevarse adelante ante un perpetrador? ¿Ante la cámara, debe el perpetrador tener los mismos derechos a la intimidad que las víctimas? En esa dirección, también puede ser mencionado uno de los esfuerzos más interesantes en el empleo de la participación de perpetradores en el documental: la serie producida para la BBC por Laurence Rees The Nazis: A Warning from History (1997). Allí, la propuesta se concentró ya no en buscar el testimonio de los grandes responsables 
del genocidio o líderes nazis sino el de gente común, gente que creyó y se comprometió con el nazismo a largo de toda Europa: cómo es que para muchos el período nazi fue un "paraíso" a pesar de los horrores de Treblinka o Auschwitz sólo podía ser respondido por los perpetradores y no por los sobrevivientes (Rees, 2005, p. 147).

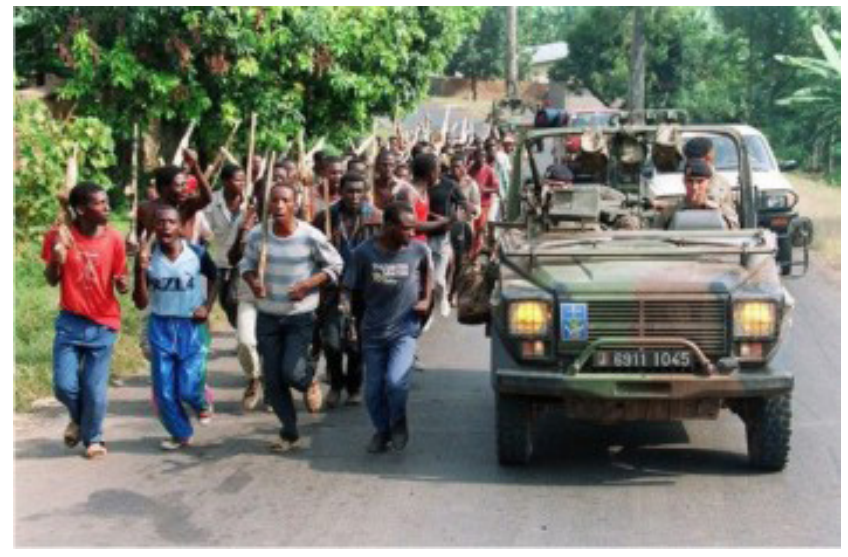

Quizá uno de los rechazos que más genera al ver a los perpetradores en la pantalla es, como ya lo señalara Hannah Arendt, su normalidad. Las memorias de varios Einsatzgruppen narradas en Das radikal Böse (Stefan Ruzowitzky, 2013) nos proveen un gran abanico de pensamientos y sensaciones que tenían las tropas especiales, y antes de ser movidos por una necesidad de hacer el mal, su tarea era, ante todo, un trabajo. En esa dirección, en sus indagaciones por la violencia humana, el psicólogo social Roy Baumeister sugiere que una de las formas de poner distancia a la normalidad del mal es pensar a este último en términos de "mal puro", señalando a esta visión de mito. Este mito no hace sino ocultar "la causalidad recíproca de la violencia”, representando "a víctimas inocentes que luchan contra enemigos malvados y sádicos"; de este modo, el mito alienta a la gente "a creer que son buenos y que seguirá siendo buena" confiriendo "una especie de inmunidad moral a las personas que creen en él” (Baumeister, 1999, pp. 95-96). Una posición similar mantiene James Waller, quien en su estudio sobre la perpetración de genocidio resalta la necesidad de comprender que en los genocidios el perpetrador se caracteriza por su normalidad; para tal fin, sugiere que en los análisis sobre éstos la pregunta no debe ser quiénes son estas personas sino cómo son estas personas que, similares a nosotros, se convirtieron en perpetradores de genocidio. Por lo tanto, si entendemos al genocidio como un proceso resulta también sugerente poder pensar los marcos sociales del mal, de qué manera, en qué circunstancias y bajo qué influencias psicológicas se au- toriza a gente normal a matar, a convertirse en asesinos en masa (Waller, 2007).

El tercer elemento humano se caracteriza por los espectadores (bystander). Sobre este actor hay escasas producciones sobre él, soliendo ser mencionado en los diversos documentales y en sus variados y complejos matices pero sin ahondarlo en profundidad. Pese a ello, se dan varias modulaciones en su caracterización que permiten complejizar a este actor. Por un lado, encontramos documentales en torno a varias modalidades de resistencia a regímenes genocidas, como The Restless Conscience: Resistance to Hitler Within Germany (Hava Kohav Beller, 1992). Por el otro, la mención de la inacción del resto de los países cuando los genocidios tenían lugar como en Armenian genocide o Ghosts of Rwanda. Los bystander también resultan de una caracterización, que a veces los colocan más próximo a los perpetradores, como en Shoah, donde escuchamos los testimonios de los campesinos polacos que cuentan como observaban la deportación de los judíos, o de meros testigos, como se hace a la sociedad toda en La República Perdida II (Miguel Perez, 1986). Este complejo actor también es el personaje central de Portrecista(Ireneusz Dobrowolski, 2006), un documental sobre Wilhelm Brasse, prisionero y fotógrafo de Auschwitz. A partir de su testimonio, de la descripción de sus tareas, ¿cómo pensar su posición? ¿Brasse fue una víctima? ¿Un espectador? $¿ \mathrm{O}$, en tanto herramienta de los nazis un perpetrador? En la exploración de recuerdos sobre la desaparición de sus padres y su vida en el campo, Albertina Carri en Los Rubios (2003) intenta hablar con los vecinos de la casa donde vivían con sus padres, dando éstos una versión de los hechos con temor, distancia y desconfianza; incluso recuerdan a esa familia como rubios -siendo todos los integrantes de pelo oscuro-: esto da cuenta no sólo de las distorsiones de la memoria sino también cómo era vista esa familia, como algo extraño y llamativo, en ese barrio. Sin dudas, uno de los films de mayor resonancia sobre este actor es Shake Hands with the Devil: The Journey of Roméo Dallaire (Peter Raymont, 2004). Inspirado en las memorias del General a cargo de la Misión de las Naciones Unidas en Ruanda, misión que tenía como objetivo monitorear la apertura democrática luego de la guerra civil, Roméo Dallaire quizá sea la figura del bystander por excelencia. Según su relato, la ONU poseía todos los medios para detener el genocidio sin embargo las órdenes de sus superiores eran no intervenir; de este modo, $\mathrm{Da}$ llaire observó cómo las matanzas se sucedían sin poder intervenir. El debate en torno a qué pudo haber hecho 
escapa al propósito de esta investigación, sin embargo, en los diversos documentales donde Dallaire da testimonio, como en el film de Raymont, éste es caracterizado como un héroe. A pesar de su fracaso, su persona queda a salvo mientras que es la institución la que queda señalada como la que impidió la detención del genocidio. En ese sentido, el film de Raymont se concentra en el regreso de Dallaire a Ruanda con motivo del décimo aniversario del genocidio, buscando en ese viaje una forma de redención a pesar de su fracaso.

\section{Tres actores más}

Quisiera señalar, a continuación, tres actores más que no forman parte de la tríada característica los estudios sobre genocidio y que de alguna u otra manera resultan de interés para profundizar en las ramificaciones y consecuencias del genocidio como en los "elementos humanos" que han emergido en la producción documental.

Al primero lo denominaré el experto, que tiene como función dar cuenta de los debates históricos o de detalles contextuales. Por lo general no tiene un vínculo vivencial con lo acontecido, lo que le brinda una posición de objetividad y verdad exponiendo los hechos, brindando conclusiones e interpretaciones. Su participación es la que puede autorizar, por medio del montaje, la veracidad de las imágenes de archivo; a su vez, su voz permite complementar, enmarcar e interpretar lo que los testigos directos vivenciaron. De este modo, en Armenian Genocide (Andrew Goldberg, 2006), Vahakn Dadrian es uno de los que lleva adelante el relato histórico del genocidio armenio, Raul Hilberg lo hace en Shoah, Samantha Power lo hace en Ghosts of Rwanda (Greg Baker, 2004) $\mathrm{y}$ en Watchers of the Sky (Edet Belzberg, 2014), David Chandler y Ben Kiernan lo hacen para el capítulo sobre Pol Pot en la serie The Most Evil Men and Women in History (2001). La experimental Das radikal Böse (Stefan Ruzowitzky, 2013) construye su soporte documental a partir del testimonio de múltiples expertos como Robert Jay Lifton, Christopher Browning o Patrick Desbois, entre otros.

$\mathrm{Al}$ segundo lo denominaré el activista. En numerosos documentales esta figura suele ser posicionada en el mismo nivel testimonial que el experto o del bystander, lo cierto es que su participación en los hechos resulta más activa y vivencial. Con todo, en diversos títulos su voz se diluye entre la de otros testimoniantes como es el caso de Philippe Gaillard, de la Cruz Roja Internacional, en Ghosts of Rwanda. En ese sentido, hay un número de films dedicados especialmente a una o varias figuras que, a modo de Quijote luchando contra los molinos, lleva adelante diversas tareas de concientización o búsqueda de justicia. Así, muchas de estas producciones tienen como función retórica la de concientizar, haciendo ello en dos niveles: por un lado, documentando la labor del actor; por el otro, dirigiéndose al espectador, en tanto bystander, para que active de algún modo contra la injusticia, intervenga o bien tome conciencia de la dimensión de determinado genocidio. En Triage: Dr. James Orbinski’s Humanitarian Dilemma (Patrick Reed, 2008), la cámara sigue al Dr. James Orbinski, ex presidente de Médicos sin Fronteras, en su regreso a diversos países africanos que sufrieron desastres humanitarios -Ruanda luego del genocidio, por ejemplo-para reflexionar sobre la posibilidad de llevar paz a aquellos que sufren como también sobre las posibilidades políticas de las ayudas humanitarias. Watchers of the Sky (Edet Belzberg, 2014) sigue a cuatro personajes que continúan el mandato de Lemkin de luchar contra toda forma de genocidio; a la vez que se traza una biografía del jurista polaco, el documental plantea las relaciones entre política y genocidio en la lucha de Luis Moreno Ocampo, fiscal del Corte Penal Internacional, por llevar a juicio a Omar al Bashir, presidente de Sudán, o la de Emmanuel Uwurukundo, sobreviviente del genocidio ruandés que realiza asistencia humanitaria en los campos de refugiados en Chad. Screamers (Carla Garapedian, 2006) a la vez que relata la historia del genocidio armenio y de otros casos -como Ruanda o Darfursigue al grupo de rock System of a Down, cuyo cantante es descendiente de sobrevivientes del genocidio armenio, en su lucha para que dicho crimen sea reconocido por el gobierno estadounidense; al mismo tiempo, al reflexionar sobre la naturaleza del genocidio, el film muestra la posibilidad de la gente común para detener próximos genocidios. Una caracterización similar se efectúa en Darfur Now (Ted Baum, 2007), donde se presenta a varias personas que llevan adelante diversas tareas de concientización y reclamo por declarar como genocidio a los hechos en el territorio sudanés. Lo sugerente de este documental es que además de personalidades del espectáculo, como los actores George Clooney o Don Cheadle, el film se concentra en la figura de Adam Sterlig, caracterizándolo como un hombre común que con sus esfuerzos y voluntad logró que el gobernador Arnold Schwarzenegger firme un proyecto de ley sobre Darfur.

Este tipo de caracterización, la del hombre común luchando contra gigantes, es la que también se emplea 
en The Devil Came on Horseback (Ricki Stern y Annie Sundberg, 2007), donde se nos presenta a Brian Steidle, un ex marine devenido en fotógrafo quien luego de ser testigo de los hechos en Darfur se dispone a emplear sus imágenes como forma de concientización. La caracterización de Steidle efectúa un recorrido singular: de soldado a espectador luego de testigo a activista culminando como un héroe moral, exponiendo la idea de que, en el marco de un exterminio en masa, un hombre común puede influir y modificar el destino genocida de un grupo. Finalmente, el actor social principal de Brother Number One (Annie Goldson y Peter Gilbert, 2011) es delineado de igual forma. Rob Hamill, un conocido deportista neozelandés y ex candidato al parlamento de en país natal, cuenta la historia de su hermano Kerry, encarcelado y asesinado en Tuol Sleng luego de ser detenido por navegar en aguas camboyanas, y su búsqueda personal por lograr justicia. En su lucha, llegando a testificar en el juicio contra Duch, su voz se alza no solo por su hermano sino por todas las víctimas camboyanas como también las de cualquier otra forma de violencia estatal.

El tercero, finalmente, lo denominaré el inconformista. Sugiero este actor al repasar documentales como Juan, como si nada bubiera sucedido, Los Rubios (Albertina Carri, 2003), $M$ (Nicolás Prividera, 2007), New Year Baby (Socheata Poeuv, 2006), 2 oder 3 Dinge, die ich von ihm weiß (Malte Ludin, 2005), The Flat (Arnon Goldfinger, 2011) e incluso What our Fathers Did (David Evans, 2015). Estos títulos comparten varias cuestiones en común, ante todo que son en primera persona (o primera persona enmascarada), luego que sus protagonistas suelen ser bijos, segunda generación, y, finalmente, que el protagonista -por lo general el mismo director o desplazando su persona a otro actor social- no se conforma con la "versión oficial" de los hechos, con los secretos familiares o con la injusticia. Así, en Juan, como si nada bubiera sucedido Esteban Buch intenta hacer justicia por Juan Herman, único desaparecido de Bariloche, cuando el poder judicial no pudo -o no quiso- hacerlo; al dar con y exponer a los diversos responsables de la desaparición del joven, el film funciona como una cámara-justicia o, como sugiere Jorge Ruffinelli, un escrache fílmico (Ruffinelli, 2005, p. 307). Los Rubios y $M$ resultan ser exploraciones sobre la militancia de los padres y las influencias de ésta sobre ambos directores pero la modalidad en que la exploran quiebran los estándares establecidos; de este modo, lejos están de continuar el estilo de los padres sino que en tanto hijos se diferencian generacional como estéticamente. New Year Baby, The Flat y 2 oder 3 Dinge... son títulos en los cuales los realizadores o bien deben lidiar con un secreto familiar o con las formas de elaboración del genocidio en el seno familiar. En la primera, Socheata Poeuv llevará a su familia a Camboya para descubrir que sus hermanos no son sus consanguíneos sino hijos de otros parientes que fueron asesinados durante el genocidio; el film de Goldfinger hace frente a la amistosa relación -que incluía vacaciones juntos- entre sus abuelos judíos y un SS antes y después del Holocausto; finalmente, el film de Maltin bucea las formas en que sus hermanas y sus familias hacen frente a la marca de Caín: esto es, ser descendiente de un importante cuadro nazi. Finalmente, What Our Fathers Did plantea un diálogo entre Niklas Frank y Horst von Wächter, hijos de dos relevantes jerarcas nazis, mediado por el abogado especialista en Derechos Humanos Philippe Sands; en sus viajes conversatorios por diversas partes de $\mathrm{Eu}-$ ropa, Frank desarrollará su punto de vista crítico acerca de su padre mientras que von Wächter se negará a ver del mismo modo a su progenitor. De este modo, en el corazón del documental se encuentra la pregunta fundamental que todo hijo de genocida se hace en torno a su padre: ¿debo amarlo a pesar de todo ${ }^{8}$ Con todo, la figura más relevante en este film es el propio Frank ya que es él quien plantea las preguntas -y respuestas-incómodas como ciertas reflexiones políticamente incorrectas sobre su relación con la sombra de su padre.

La ética en el documental no sólo puede estudiarse en torno al elemento humano, también puede ser discutida a partir del tratamiento sonoro que el realizador efectúa, ya sea la musicalización - una forma de caracterizarcomo también la banda sonora -La República Perdida II o la serie Apocalypse (Isabelle Clarke y Daniel Costelle, 2011-2016), por ejemplo, son dos documentales de compilación que en su montaje agregan efectos de sonido o foley a las imágenes-. Eso lleva también a discutir en términos éticos el uso y creación de nuevos sentidos efectuados por medio del montaje; es decir, cómo el material de archivo es conducido a un proceso de designificación-resignificación. Asimismo, en términos del uso de materiales de archivo se halla también la controversia en relación al horror: ¿se deben mostrar las imágenes más conmocionantes? ¿Ayuda la mostración de dichas a imágenes a imaginar lo inimaginable, a conocer? ¿Ayudan a construir una verdad sobre lo sucedido?

Existe también otra posible discusión ética: la postura del realizador ante los hechos. Todo documental sobre genocidio no solo intenta presentar evidencia o testimonios sino que también ofrece una interpretación sobre 
el caso; así, ¿qué consecuencias puede acarrear la interpretación que se efectúe? ¿Cuál es la responsabilidad del realizador al ofrecer una perspectiva determinada sobre el genocidio expuesto?

Con más preguntas que respuestas, lejos de establecer un deber ser, intenté plantear problemas y debates que lejos están de clausurar en una normativa única y particular; así, las discusiones solo quedan resueltas en formas paradojales o de aporías. Esto se debe a que la posición ética, tal como presenté a lo largo del trabajo, no es unívoca sino variable tanto para diversos documentales sobre un caso determinado como incluso en una misma producción. En última instancia es el realizador quien debe enfrentar y asumir una actitud ante estos problemas, tomar posición y responsabilizarse por sus decisiones.

\section{Referencias}

Alvarez, A. (2001). Governments, citizens, and genocide: a comparative and interdisciplinary approach. Bloomington: Indiana University Press.

Baumeister, R. (1999). Evil. Inside Human Violence and Cruelty. Nueva York: W. H. Freeman and Company.

Burucúa, J. E., \& Kwiatkowski, N. (2014). «Cómo sucedieron estas cosas». Representar masacres y genocidios. Buenos Aires: Katz.

Lanzmann, C. (2011). La liebre de la Patagonia. Buenos Aires: Seix Barral. Nichols, B. (2007). Cuestiones de ética y cine documental. Archivos de la Filmoteca, 57.

Plantinga, C. (2007). Caracterización y ética en el género documental. Archivos de la Filmoteca, 57.

Rees, L. (2005). The Nazis: A Warning from History. En T. Haggith\& J. Newman (Eds.), Holocaust and the Moving Image. Representations in film and television since 1933. Londres: Wallflower.

Ruffinelli, J. (2005). Documental político en América Latina: un largo y un corto camino a casa (década de 1990 y comienzos del siglo XXI)”. En C. Torreiro\& J. Cerdán (Eds.), Documental y vanguardia. Madrid: Cátedra.

Ternon, Y. (1995). El estado criminal. Los genocidios en el siglo XX. Barcelona: Península.

Waller, J. (2007). Becoming Evil. How Ordinary People Commit Genocide and Mass Killing. Nueva York: Oxford University Press. Wieviorka, A. (2006). The Era of Witness. Ithaca: Cornell University Press.

Winston, B. (2005). Ethics. En A. Rosenthal \& J. Corner (Eds.), New Challenges for Documentary. Manchester: Manchester University Press.

1 Plantinga se refiere a los personajes y no a los actores. Desde ya que para el cine de ficción se puede pensar una ética de trabajo particular.

2 Se podría sumar un actor más: la narración en off en tanto "voz de Dios". Si bien no es necesariamente un actor, este recurso es el que le permite al director enmascarar su posición bajo un halo de objetividad.

3 Por ejemplo, el libro de memorias L'Espèce humaine de Robert Antelme fue publicado en 1947 y la novela autobiográfica La nuit de Elie Wiesel fue publicado originalmente en 1956.

4 Los textos en off de Nuit et brouillard (Alain Resnais, 1956) pertenecen a Jean Cayrol, sobreviviente del campo de Gusen. Para Le temps du ghetto (Frédéric Rossif, 1961) se utilizó como textos en off algunos escritos que fueron recuperados de los archivos clandestinos enterrados entre las ruinas del gueto.

$5 \quad$ Si bien en 1964 The Pawnbroker (Sidnely Lumet) dio por primera vez espacio al sobreviviente del Holocausto como personaje protagónico de un film, fue la controvertida miniserie Holocaust (Marvin Chomsky, 1978) la que despertó un interés mayor por la palabra de los sobrevivientes del Holocausto; de este modo, uno de los primeros documentales estadounidenses en torno a esta figura fue Kitty: Return to Auschwitz (Peter Morley, 1979).

6 De hecho, el afiche de dicho film remite a esa escena: Basch sentado en el campo, en llanto, cubriéndose la cara.

7 Es preciso señalar que Suchomel no es el único nazi filmado en Shoah. También recurrió a la cámara oculta y al incumplimiento de no mencionar su nombre para registrar el testimonio de Franz Schalling, guardia en el campo de Chełmno, y de Walter Stier, jefe de de la oficina de administración de los ferrocarriles del Reich. También filmó, en forma esquiva, a Joseph Oberhauser, un oficial nazi en el campo de Beł邓ec.

8 Esta pregunta se repite en varios documentales que tienen a descendientes nazis como protagonistas. 